\title{
CSNK1D Gene
}

National Cancer Institute

\section{Source}

National Cancer Institute. CSNK1D Gene. NCI Thesaurus. Code C125588.

This gene is involved in cellular growth and survival processes. 